\title{
The Professional Associations
}

\section{The forester and wildland \\ management}

Professional foresters in B.C. have developed a soundly organized base through the Association of British Columbia Professional Foresters, which was formed in 1947. At the Association's Annual Meeting in Victoria last February, the profession decided that it should now encourage a more outward look in its activities and become involved in public affairs, particularly those concerned with non-urban land use.

Such a policy immediately forced our members to examine our capabilities as land managers. Since most members were trained in specific forestry sciences, they were reluctant to hold forth on other matters. However, the advent of great public interest in ecology emphasizes the question of who, or what group, would be able to undertake an overall view of a many-disciplined approach to solutions of the varied ecological problems involved in optimum land use. Foresters, having probably the widest interest, training, and experience in wildland use, are coming to the conclusion that they are, or should be, the overall land managers, and that they had better "get with it", or suffer public scorn.

It is becoming clear that there are few, if any, overall land use ecologists, but there are specialists in all disciplines involved. The forester's place, then, is to use his specific talents in forestry matters and also, as land manager, to call upon the other specialist disciplines to join with him in determining optimum (or least conflicting) land uses.

It follows, therefore, that effective land use planning must be clearly explained to the public. This, of course, means that the land manager foresters must learn to work with the information media, to properly, clearly, and dispassionately bring the essentials of optimum land use decisions to public attention. Specific cases should be used, and these clearly defined and illustrated so that the resolution of the issues are well explained to the public.

It seems to me that the professional forester must, "willy-nilly", accept his managerial role in the interests of the urgent solution of wildland environmental problems.

As a Consulting Professional Forester already facing up to these problems, I believe our profession is ready, willing and able to work with the specialists and the media on such problems, to the end of public enlightenment and the public good.

Perhaps the inevitable result of acceptance of such a role would involve more Registered Professional Foresters (R.P.F.'s) in discussions on general public issues. Where this might lead, and to what ends, remain to be seen, but I suggest it is worth a real try, fellow R.P.F.'s.

M. W. Gormely, R.P.F., P.Eng.,

President

Association of B.C. Professiona! Engineers

\section{Corporation des} \section{ingénieurs forestiers de la Province de Québec}

At the 50th annual meeting of the Corporation des ingénieurs forestiers de la Province de Québec it was proposed, and adopted unanimously, that la Faculté de foresterie et de géodésie de I'Université Laval and the Minister of Education write into their study program an option on urban forestry.

Another motion, adopted unanimously, proposed that the Corporation ask that I'Université La$\mathrm{val}$ and the Minister of Education provide an adequate budget for the expansion of la Faculté and its already established projects.

It was also proposed that the annual membership dues be increased from $\$ 65$ to $\$ 75$.

The Executive Committee for 1970-71 consists of M. Julien Rivest (President), M. René Rinfret (Vice-President), M. Hughes Fortin (Treasurer) and M. Adrien Dubé and M. JeanClaude Mercier (Councillors). In addition to these men, the following make up the Administrative Council for the same period: $M$. Arthur Bérubé, M. André Demers, M. Henri Gauthier, M. Gaston-M. Guay, M. Laurent Létourneau, M. Marcel Léveillé, M. Jean-Paul Nadeau, M. J.-Ralph Pitre, M. P. H. Tremblay and M. Herbert I. Winer. 
Citizenship

\section{requirement not}

\section{necessary for \\ Quebec registration}

The Liberal government in Quebec has introduced its first piece of legislation designed to foster the integration of immigrants into the province's French-speaking milieu.

Under terms of Bill 64, future immigrants would not be admitted to 19 medical and technical corporations unless they have "a working knowledge" of French. Forest engineers are among those affected.

The Bill will not force integration into the French milieu but it will make it impossible for many immigrants to settle in Quebec without this undefined "working knowledge."

Up until now, a person has had to obtain his Canadian citizenship before being admitted to many of the corporations and associations mentioned in Bill 64. This requirement is removed provided the immigrant applied for his citizenship "within the minimum legal delays." This means that none of the corporations may refuse a candidate for the sole reason that he is not a Canadian citizen.

Adapted from The Gazette

\section{The forester in}

\section{the management of ecosystems ${ }^{1}$}

The professional forester is being asked ever more often to undertake the responsibility of managing our forests and forest land for all of the diverse products we expect from a balanced, natural ecosystem. At the same time, our understanding of the properties of whole ecosystems is becoming a science in itself. It is a science far more complex than anything ordinarily encountered in a four year professional fores-

${ }^{1}$ Presented at the Annual Meeting, OPFA, November 1970. try program. Therefore the obvious question faces us: "How can any forest manager be expected to manipulate such a system with enough precision to optimize yield of the desired products, including environmental quality, over large areas, and under a progression of changing conditions?" We also have to recognize the frequent answer, "If forestry will not meet its obligations in ecosystem management. there are other professional groups more than willing to do so, and they should have that opportunity now."

Computer simulation of whole ecosystems will be a practical management tool within the next four or five years. For the time being, it is feasible for many professional foresters to use many of the components that are going into these ecosystem models. The goal of the simulation studies is to examine precisely the results in the year 2000 of choosing among the options available now. This is done by letting the system run over a period of twenty to fifty years within a matter of minutes on the computer, and examining outputs expressed as impacts on the products desired. Implementation of this computer simulation capability is leading to much clarification and simplification of what we once viewed as very complex, qualitative relationships. We now see them as a series of relatively direct, simple quantitative relationships.

But one does not have to carry out an entire simulation in order to take advantage of the recent improvements in understanding. For the time being we can do much by only listing all of the quantitative relationships that need to be considered. The forester can improve his effectiveness and objectivity considerably by evaluating options available against a background of the quantitative relationships recognized. Such things as the form of the equations, and magnitude of the time-lags involved, help him assess the impact of changing recreation on the diverse products expected from the land resource twenty-five years from now.
The steps in carrying out an intermediate level of ecosystem analysis could be given in a senior level course, or in the type of professional retraining courses offered at the University of Wisconsin for the U.S. Forest Service personnel. The techniques of projecting whole ecosystem equilibrium relations twenty-five years into the future have been developed around the need to project nutrient buildup and impact on lake and stream systems over this time period. The methods have served effectually in several court tests of the feasibility and desirability of granting permits to developers for constructing dams and cottage sub-divisions of up to 2,000 family units. The methods also have been extended to simulation of regional forest and agricultural land allocation strategies and are being used to advise real estate developers in large suburban areas.

Orie L. Loucks

University of Wiscosin

OPFA Officers and Councillors for 1970-71

PRESIDENT: K. W. Hearnden By Acclamation

VICE-PRESIDENT. W. W. Hall By Acclamation

\section{COUNCILLORS}

NORTHERN SECTION: M. A. Wilson

CENTRAL SECTION: R. A. Haig SOUTHERN SECTION: R. N. Staley

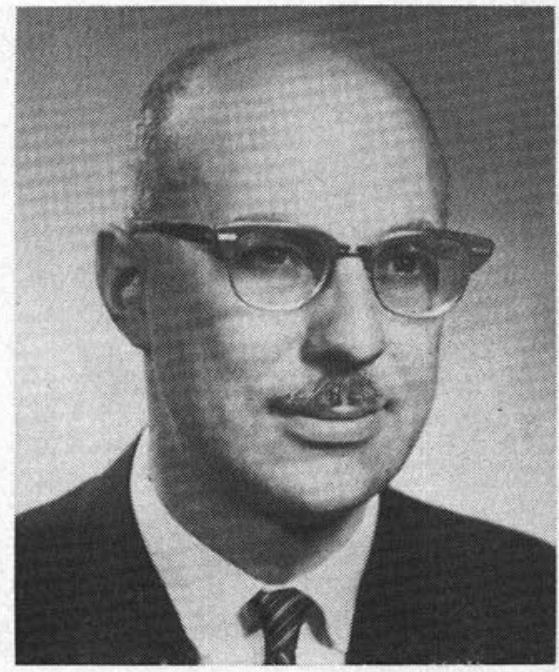

K. W. Hearnden 